\title{
Anglican Cathedrals in a Secular Society: David Martin and the Sociology of English Religion
}

\author{
Martyn Percy ${ }^{1}$ \\ Published online: 16 March 2020 \\ (C) The Author(s) 2020
}

\begin{abstract}
One of the puzzles in our secular age is the resurgence in attendance at English Cathedrals. Whilst it is commonplace for sociologists and media - and sometimes church leaders - to draw attention to burgeoning membership in evangelical and charismatic churches, the Cathedrals of the Church of England represent a different kind of growth. A considerable number of attendees come to cathedral worship and significant commemorative events (e.g., Christmas, Remembrance) because the very particular ecclesial ecology of a cathedral does not normally require membership, intense fellowship or frequency in attendance. Cathedrals, therefore, are now more prominent exponents of 'low-threshold-high-reward' patterns of worship, and point to a form of ecclesial polity that was once much more common in English Anglicanism. Namely, the church serving its community as a support-based institution rather than as a member-based organisation. The sensibility of cathedral worship may now chime more deeply with those latent patterns of spirituality that remain textured and strong within the weave contemporary culture, embodying spiritual-spatial inclusion. To understand the resilience of cathedrals, and their relative growth in attendees, requires developed ecologies of English church-going that comprehend the value of the church continuing to hold its vocation as the social skin of a city, region and the nation, and a patterning of polity that continually renews the values underpinning civic society.
\end{abstract}

Keywords Cathedrals · English religion · Secularization, Anglican · Threshold-reward, Ecclesiology

Just as Garrison Keillor might say of Lake Wobegon, "it has been a quiet few weeks at Christ Church Cathedral". On Monday the Cathedral presided over the funeral of Police Constable Andrew Harper - a service attended by over 500 officers of the Thames Valley Police Force, and watched by another 1500. The streets of Oxford fell silent as the coffin processed, and thousands of bystanders paid their respects. PC Harper lost his life in the line of duty in August 2019. The Home Secretary, the Chief Constable, Lord Lieutenant, High Sherriff and local MP's were in attendance. On Tuesday the Cathedral hosted the annual Court Sermon - with High, County and District judges in attendance, along with the mayors, sheriffs and others from the legal present. The Cathedral was again full. Later that week the College of Canons gathered from across the three counties of the Diocese for the Patronal Festival of Saint Frideswide. Then

Martyn Percy

martynwpercy@gmail.com

1 Christ Church, Oxford, England OX1 1DP, UK there was the annual Civic Service (this year especially celebrating those arts charities working with children who have disabilities), and the annual Diocesan Pilgrimage to the shrine of Saint Frideswide. Packed around these celebrations is the daily rhythm of morning and evening prayer, of holy communion and thousands of tourists spilling into the space. Sundays are always focussed on Matins, the Eucharist and Evensong. The Cathedral is a welcoming host for many needs and hopes. It is a common plot and open place, which is more than the sum of its parts. It embodies in its architectural and temporal assemblage a simple message: that this building and what it hosts and offers belong to a wider public. One could be forgiven for thinking that northern Europe continues everonwards to a more secular existence. However, if you worship in an English Anglican Cathedral on a regular basis, this will not be your experience. In this brief and rather eclectic reflection on English religion, society secularisation, I propose to reflect on just some of the reasons why Anglican cathedrals seem to be faring rather well, when church-going is in decline. Inevitably, perhaps, this will be a discursive essay, and as we proceed, I wish to record a debt to my ongoing engagement with four seminal texts from David Martin's distinguished 
corpus, and that I have cherished over the years: The Sociology of English Religion (London: SCM Press, 1967); The Breaking of the Image (Oxford: Basil Blackwell, 1980); Christian Language and its Mutations (Aldershot: Ashgate, 2002); and Christian Language and the Secular City (Aldershot: Ashgate, 2002). This personal canon is not exhaustive, to be sure. Within the field of the sociology of religion, David Martin was a colossus. His contributions to the field span secularisation, Pentecostalism, music, violence, ecclesiology, social change and more besides.

Time spent with David and with his work was gold. Every sentence of every book was packed with nuance, learning and wisdom; and also with empathy and humanity. Together with his wife Bernice (herself a distinguished sociologist from Bedford College, London University), David was one of the most remarkable leaders in his field for more than fifty years. Serving as a Methodist local preacher before being received and ordained into the Church of England, David was an advocate of the Prayer Book and the Authorised Version of the Bible on sound sociological, linguistic and pedagogical reasons. Over the three decades that I knew David personally, he was regular worshipper at Guildford Cathedral, and we often spoke of about the role of such buildings in civic life and wider society, and of course our conversations frequently focussed on the study and state of contemporary Anglicanism.

Martin's critiques of secularisation - for which he is probably best-known - began early in his academic career. He arguably devised one of the very first of them in his 1965 essay, 'Towards Eliminating the Concept of Secularisation'. It is difficult to overstate the significance of this prescient study. The sociology of religion was rooted - some would say founded - on the premise that as advanced modern societies developed, they essentially became less religious. But Martin's work, iconoclastically, said that this was not the case. This study was followed by 'Notes for a General Theory of Secularisation' (1969), later published as A General Theory of Secularisation (1978). This remains one of the landmark texts in the history of secularisation studies. Even in retirement, Martin continued to contribute to debates on secularisation, as well as the surprising resilience, mutations and effervescence of religion in the twenty-first century. Some evidence for such resilience, mutations and effervescence is found in the growth of Pentecostalism; and Martin's work has looked at Latin America, with its developing economies and new urban sprawls, to show how religion can grow and prosper in modern societies.

\section{Secularisation, Cathedrals and English Religion}

It is fair to say that most Cathedrals in the Church of England possess their own unique and complex 'ecclesial DNA'. Some began as monasteries, whilst others as parish churches. Some were purpose-built; but others may no longer reside in the bounds of the original span of the diocese. Some are ancient, some modern. Most are a mixture of the two. David Martin commenting on English churches more generally, notes that

We in England live in the chill religious vapours of northern Europe, where moribund religious establishments loom over populations that mostly do not enter churches for active worship even if they entertain inchoate beliefs. Yet these establishments guard and maintain thousands of Houses of God, which are markers of space and time. ${ }^{1}$

The recent British Social Attitudes Survey seems to confirm those 'chill religious vapours', as the survey found that whereas $33 \%$ of Britons aged over 75 still identify as Anglican, the figure for the $18-24$ 's is just $1 \%$. In the Netherlands, $15 \%$ of Roman Catholic churches have been desacralized in the last twenty-five years, and the figures for Protestant churches are $25 \%$ - a quarter of the buildings have now been put to alternative use. To be sure, it is something of a trope to say that whilst individuals become less religious, they become more spiritual; or that whilst belonging declines, believing persists. The sociology of religion continues to propagate such binaries with characteristic suppleness. However, I want to add one more dimension to the debate. Namely, that with every advance that secularisation may take, sacralisation keeps in step.

For many English people in the twenty-first century, religious establishments are perceived to have weathered rather badly. Secularisation and consumerism, coupled to a declining number of those who follow faith, and a perceived loss of integrity in the religious institutions, has led many to question the future of public religion. However, Martin suggests that the buildings - these very stones - still speak to us:

Not only are they [i.e. churches] markers and anchors, but also the only repositories of all-embracing meanings pointing beyond the immediate to the ultimate. They are the only institutions that deal in tears and concern themselves with the breaking points of human existence. They provide frames of reference and narratives and signs to live by and offer persistent points of reference. They are repositories of signs about miraculous birth and redemptive sacrifice, shared tables and gift-giving; and they offer moral codes and exemplars for the creation of communal solidarity and the nourishment of virtue. They are places from which to launch initiatives which help sustain the kind of networks found, for example, in the inner city; they welcome schools and

\footnotetext{
${ }^{1}$ David Martin, 'Believing without Belonging', cited in Grace Davie, Religion in Britain Since 1945, Oxford: Blackwell, 1991, p. 189.
} 
regiments and rotary clubs; they are islands of quietness; they are places in which unique gestures occur of blessing, distribution and obeisance; they offer spaces in which solemnly to gather, to sing, to lay flowers, and light candles. They are - in Philip Larkin's phrase serious places on serious earth'. ${ }^{2}$ Cathedrals are primary exemplars here: ultimate places of spiritual spatial inclusion.

Yet, there is no denying that in the twenty-first century, there is general anxiety about apparently declining numbers of attendees at regular Sunday worship in the Church of England. However, at least one group of churches has bucked the trend: the cathedrals. Consistently, the numbers worshipping in English Anglican cathedrals have been resilient, immune to the decline seen elsewhere. Indeed, many cathedrals report an increase in the number of worshippers. But what do these numbers actually show? As with much statistical analysis, it is the story behind the numbers that tells us how to interpret the bare arithmetic. To understand the growth of worshippers in cathedrals, one needs to have some grasp of the nuanced ecology of English church-going. Here I draw on conversations with David, and am especially mindful of his view - that I share - that Anglicanism, at least in its English form, is a support-based institution rather than a memberbased organisation. To be sure, one perpetual question that Anglicanism faces today is, 'Who is Anglican?'. However, any investment in an overly narrow specifications of membership will have profound consequences for the identity and organisational shape of Anglican ecclesiology, including performative-liturgical arenas such as baptism. The sociocultural expectations that are invested by those outside the worshipping congregation in baptism require constant local, pastoral negotiation between churches, clergy and the communities they serve. The socio-theological vision of Anglican polity therefore needs to understand its purpose and roots more deeply. Theology and the supernatural authority of the church, which she is called to embody and proclaim, cannot simply allow its ethos, identity and practice to be replaced with what I have consistently termed 'consecrated pragmatism?. ${ }^{3}$ This is particularly the case in relation to how people become part of a social and spiritual body, like the church, that is fundamentally inclusive in nature and character.

The current turn toward ecclesial organisation and management, focuses particular attention on how people become part of the church. ${ }^{4}$ Specifically, it presses the question as to

\footnotetext{
${ }^{2}$ Martin in Davie, $1991, \mathrm{p}, 190$.

${ }^{3}$ For my earliest discussion of this, see Martyn Percy, 'Consecrated Pragmatism', Anvil, Volume 14, No. 1, 1997, pp. 18-28.

${ }^{4}$ The background to the distinction between organisation and institution lies in the writings of Philip Selznick. For a discussion of his work in this field, see Martin Krygier, Philip Selznick: Ideals in the World, Stanford: Stanford University Law Books, 2012.
}

whether the global expressions of Anglican polity are distinctive, bounded and overtly member-based organisations in character, seeking clarity of identity, or whether they are broader social and sacramental institutions to which a much wider public relates in a variety of ways. I am mindful that most ecclesial ecologies will contain both of these elements and will be a blend of those who feel a sense of strong attachment (often expressed as 'membership'), and those whose basically affirmative relationship to the church involves a more variegated form of commitment. (My concern has always been with the concept of membership in Anglican polity as a whole. ${ }^{5}$ ). If the church is consumed with its own managerial and organisational goals, including increasing its own numerical growth and intensifying the commitment of its members, it will have lost its soul. I hold, in contrast, that global Anglican polity posits a rather more incorporative model of church; a non-member-based institution that seeks to serve society as a whole, rather than a member-based organisation that primarily exists for its committed subscribers.

In her prescient book, The Precarious Organisation, ${ }^{6}$ the Dutch sociologist and ecclesiologist Mady Thung suggests that national churches in Northern Europe have come under increasing pressure in the post-war years to become selfconsciously 'organisations', marked by 'nervous activity and hectic programmes ... constantly try[ing] to engage' their members in an attempt to reach 'non-members'. She contrasts the 'organisational' model and its frenetic activism with the 'institutional' model of the church - the latter offering, instead, contemplative, aesthetic and liturgical models that take longer to grow and are often latent for significant periods of time, but which may be more culturally resilient and conducive than those of the activist-organisational model. Thung concluded her book by suggesting that the model being adopted by many national churches - a kind of missional 'organisation-activist' approach - is what drives the population away. It leads, logically, to sectarianism.

Church-going in Anglican polity has generally been a matter of relating to and inhabiting a complex institution, where the idea of 'membership' of a subscriber-based organisation is seen as a more 'Congregationalist' kind of ecclesiology. I mean no disrespect to Non-Conformist chapels and congregations here. I simply draw attention to the fact that a parish

\footnotetext{
${ }^{5}$ On this, see Paul Avis (ed.), The Journey of Christian Initiation: Theological and Pastoral Perspectives, London: Church House Publishing, 2011. See also M. Percy, Shaping the Church: The Promise of Implicit Theology, Farnham: Ashgate, 2010, for a detailed discussion of baptism as a broader cultural practice, which enables the child (i.e., having been 'blessed' and 'christened') to be received back into a local community as a recognised and publicly affirmed member of that society. For a closer ethnographic study of this phenomenon, rooted in the fishing village of Staithes on the NE coast of England, see David Clark, Between Pulpit and Pew, Cambridge: Cambridge University Press, 1982.

${ }^{6}$ Mady Thung, The Precarious Organisation: Sociological Explorations of the Church's Mission and Structure, The Hague: Mouton \& Co., 1976.
} 
church exists for the spiritual wellbeing of the whole community, and it serves that community independently of any subscription or support that the people in the community might provide. This is by no means a unique characteristic of Anglicanism. It is the form of ministry exercised by ecumenical chaplains in prisons, hospitals, schools and colleges, the armed services and other arenas, where the ministers elect to serve the whole body, not merely the committed minority. And amid the general anxiety about apparently declining numbers of attendees at regular Sunday worship in the Church of England, at least one group of churches has bucked the trend: the cathedrals. Consistently, the numbers worshipping in English Anglican cathedrals have been resilient, immune to the decline seen elsewhere. Indeed, many cathedrals report an increase in the number of worshippers. But what do these numbers actually show?

Social exchange theory can help with such interpretation. Classic cathedral worship is typically a 'low threshold' pursuit - that is to say, anyone can come, without any need or pressure to join a rota, group, class or any other supplementary activity. However, 'low threshold' is most likely combined with 'high reward': the music will invariably be superb, the preaching of a consistently high calibre and the liturgy predictable and elegant.

In contrast, the dominant preferred ecclesial model in the Church of England today is 'high threshold and high reward'. The justification for this formula is usually the priority of 'discipleship', which is preferred to anything that smacks of vicarious religion, or a lack of clarity in matters of belief. 'High-Threshold-High-Reward' churches will offer attendees a rich menu and a variety of groups and activities that they will be expected to join. The committed can be identified easily enough - by the range and scale of their involvement in groups and activities. Those who are less involved will be deemed to be, by the same token, less committed. Thresholds for joining and participating are therefore set deliberately high, and this often manifests itself in areas such as restrictive practices in respect of baptisms and marriages, and can even extend, occasionally, to restricting funerals to 'members'. 7

The problem with the 'High-Threshold-High-Reward' churches is that, whilst there is a stress on discipleship and commitment, the model of church being offered is unavoidably narrow. Moreover, the concentration of resources and monies in these ecclesial paradigms means that other churches - I do not include cathedrals here - can quickly develop into 'High-Threshold-Low-Reward' churches. By that, I mean that the instinct of affirming the church as being for everyone in

\footnotetext{
${ }^{7}$ For further discussion, see John Shelton Reed, Glorious Battle: The Cultural politics of Victorian Anglo-Catholicism, Nashville, TN: Vanderbilt University Press, 1996; and W.S.F. Pickering, Anglo-Catholicism: A Study in Religious Ambiguity, London: SPCK, 1989.
}

the community, whilst laudable, comes as a cost that falls only on a few. The quality and quantity of worship, pastoral ministry and more besides, can only operate if a few will fund this for the many. This is by no means certain.

In terms of membership of the church, the post-war story of English Anglicanism has witnessed the slow accretion of greater density towards the wings: a density, moreover, consisting not merely of numbers, but also of theological and ecclesiological intensity. Both wings - depending on whether one refers to them as high and low, evangelical and catholic - have tended to be more prescriptive about what constitutes 'membership' (not only of their own respective groups and societies, but also wider membership of the church), have been zealous on areas such as liturgy, reform and divisive debates, such as those on sexuality and gender. In this, 'baptism' as means of incorporation within the church, and symbolically too in being named to wider society, has become a rite that has attracted wider ecclesial collateral. Specifically, is 'Christening' a shared social-sacramental covenant between church and world, and God and people? Or, rather, as the high and low, or evangelical and catholic wings tend to claim, a private rite, performed in public, that inducts individuals into something more obviously bounded, organisational and contained? In addressing this issue, we remain mindful of studies that speak of baptism differently, namely as the rite performed by and in the church that confers a name and social status on the child in question. So through baptism and naming, the child becomes not only a member of the church, but also a member of the broader social community.

Thung concluded her work with something of a prophetic warning to churches, and here I include global Anglicanism. She noted the inevitability of churches needing to become more organised, and more like organisations, replete with plans for numerical growth and measurable impact. But Mady Thung also sounded a note of caution. Namely that every step churches take towards the tighter and clearer forms of organisation, coupled to overt mission and evangelism, is one further step away from the public at large, who, she claims, are looking for more open forms of institutional life, which offer more by way of open community than propositional clarity. Ultimately, Anglicanism's pastoral practice, mission and ministry does not have its identity rooted in being an eclectic and selective member-based organisation, requiring detailed confessional subscription from believers. Anglicanism is, rather, far broader: an institutional body that has many kinds of support and supporters, though with room still for those who want to regard themselves as insider-subscribers. To some extent, there are parallels between this vision of a broad church for all, and the actuality of broad-casting. Michael Sadgrove put it eloquently in a recent short essay, and quotes a 'convert' (I use the word advisedly) to BBC Radio Three's Choral Evensong. The listener writes: 
I turned on Choral Evensong by accident one afternoon a year or so ago and I've been listening ever since. The music is beautiful, but the special quality of Evensong lies in other places too, in the paradoxical contrast between the sinewy intricacy of sixteenth-century language, and the simplicity of the thoughts it expresses: prayers for courage, for grace, for protection from the dark, for a good death. These are things to which our minds have particularly lately turned in the aftermath of recent terrible events, but they were there all the time in the psalms and collects of Evensong. For almost 500 years the same words have been repeated by people in times of trouble or of triumph. The presence of that cloud of unseen witnesses lends an intangible quality to Choral Evensong. You could call it calm or spiritualty. You could call it holiness. But it's very precious ... ${ }^{8}$

This outcome was arguably not the manifest intention of the broadcaster, but it is the outcome for the listener. So where does the mission and ministry of the church belong in such a world, and perhaps especially in contemporary English culture? Clearly, it lies in keeping space for the sacred and pastoral both possible and open, as well as alive and engaged. In offering faith both to and for institutions, churches and clergy have a unique role in calling individuals and bodies to the horizons that lie beyond the scope of immediate priorities. The role might be said to consist of pastoral care in the present (of course); but pointing beyond the temporal and pragmatic to the world of the spiritual, the domain of values, and to the social transcendent. Indeed, churches continue to occupy and bridge the gap between created and redeemed sociality. The church holds the world before God. It is the social-sacramental skin for the community. It is not an enclave for the redeemed, but rather a resource for all those seeking meaning and truth in a world that longs for hope.

\section{Concluding with Cathedrals}

There is something about English Anglican cathedrals that can't be easily expressed in opinion. It is, arguably, more to do with atmosphere and temperament. As I have noted in other writing, every denomination is to some extent, and to borrow a phrase from John Caputo, an attempt to express the 'mood of God'. 9 Moreover, the sheer scale of most cathedrals - their very vastness - might have something to do with their

\footnotetext{
${ }^{8}$ Michael Sadgrove, 'Choral Evensong', Prayer Book Society Magazine, Lent 2017, pp. 11-12.

9 See Gary Gutting, 'Deconstructing God', The New York Times, 9th March 2014, in an interview with John Caputo, and discussing his book The Prayers and Tears of Jacques Derrida: Religion Without Religion, Indiana: Indiana University Press, 1997. [http://opinionator.blogs.nytimes.com/2014/ 03/09/deconstructing-god/?_r=0]
}

counter-cultural resilience. Perhaps they resist secularising trends by their size, and the shape of what goes on inside them? With respect to the kind of Anglican liturgy and churches that David and I have both cherished, I have observed that

The 'temperature' of the liturgy is therefore essentially temperate, perhaps even bordering on the cool. It is a reflective and contemplative service in which the epiphanies permeate through aesthetics, language and the complex culture we normally refer to as 'liturgy'. The proxemics (also carry) an implicit theology: that God meets us in space; indeed, respects our space as individuals. God does not crowd us. Indeed, that there is some spiritual value about being more alone in a larger sacred space - and which does something physical closeness can't convey and reify. ${ }^{10}$

Similarly, I note this telling analogy from John Milbank. A cathedral, argues Milbank, is complex, slightly contrary, encompassing space - yet naturally incomplete, and always pointing beyond itself to something other and higher:

One walks through such a building conscious of continually unfolding vistas. It is a whole, yet it cannot be seen as a whole. Nor, though it is handed down to us by the past, is it ever completely finished. New spaces expressing new needs, new altars representing a multiplicity of concerns and commitments, new decorative details celebrating new ideas and discoveries, can go on being added. It is also constantly decaying and constantly being rebuilt. It can represent both diversity, and the imperfection of incompleteness, without compromising its unity or confusing its purpose. A cathedral points beyond itself. It is not definable like a city, but open to all. Its verticality is a reminder that it is not just about human beings and human relationships. It provides a complex space which can bring home to us where, as transitory, contradictory, sinful and yet ultimately hopeful and receptive human beings, we really stand before God. ${ }^{11}$

The honouring of values and behaviours that celebrate social affinities, are rooted in a kind of 'soft' (but unspecific) Deism, and have the character of a kind of 'low-threshold' and 'common' liturgy: all may observe and participate - through silent reverence, for example - without being specifically active in the ritual. This should not surprise us. Remembrance Sunday is observed up and down the land with careful

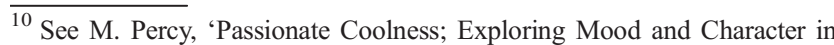
Ecclesial Polity', in D. Lemmons (ed.), Theologically Engaged Anthropology, Oxford: Oxford University Press, 2018, pp. 296-314.

${ }^{11}$ John Milbank, The Word Made Strange: Theology, Language, Culture, Oxford: Blackwell, 1997, p. 284.
} 
Fig. 1 The American Airbase Memorial Chapel, Madingley Cambridge

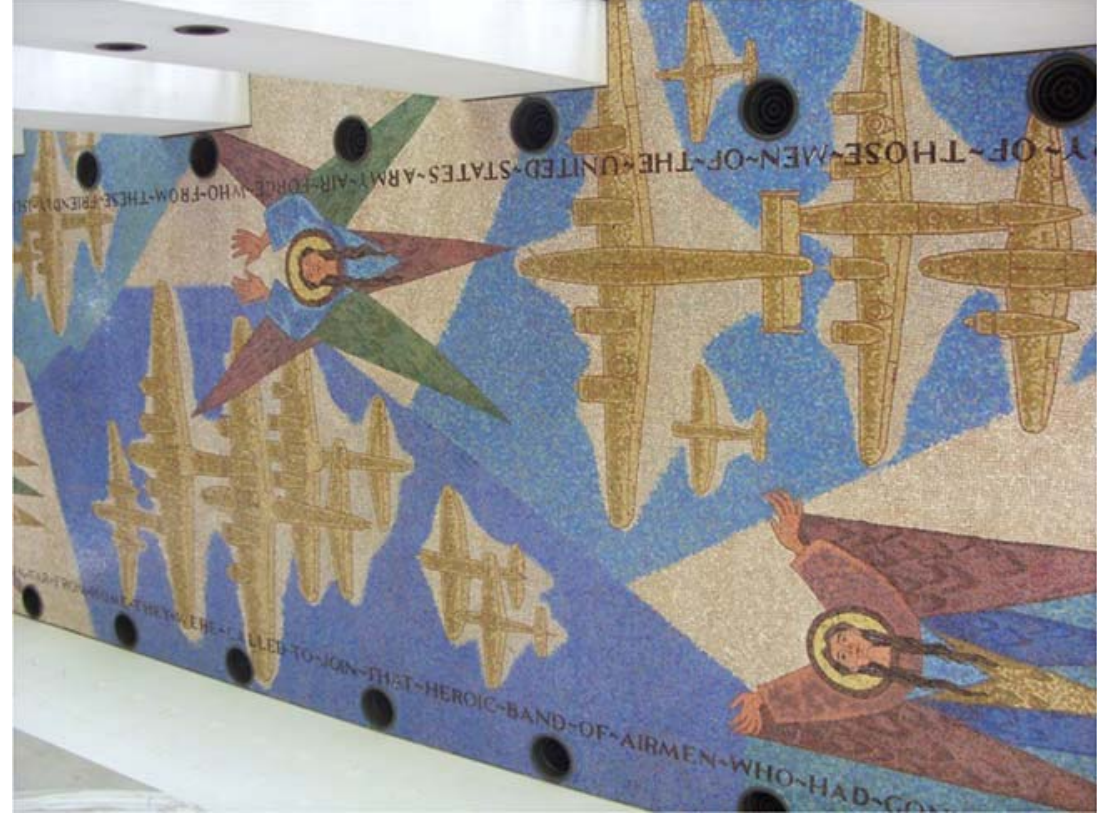

liturgical-pastoral choreography, and some parish churches now report that it is becoming more popular than Christmas. That said, the actual act of remembrance itself can be a curiously ambivalent religious phenomenon. Yet it is at same time spiritually moving, and socially binding - and a communion between the living and the dead, as well as a celebration of the best in humanity (i.e., noble sacrifice and virtues, etc.) albeit in the midst of reminding ourselves of humanity's darker side (i.e., violence and evil). Mausoleums that commemorate the dead of the two great wars of the twentieth century are often profoundly 'religious', even when they are not. ${ }^{12}$

David Martin made this same point in analysing the American Airforce War Memorial at Madingley, in Cambridge $^{13}$ (See Figure 1). The chapel is almost devoid of religious symbols. And yet the mosaic of aeroplanes that adorn the ceiling above the names of the dead, hovers over them like so many Christian crosses. They are accompanied by winged messengers - angels. The elision of the angels and the bombers says, somehow, that these airmen are with the angels; that these winged messengers ultimately brought a message of peace, not war to the continent they fought to liberate. There is a fenced off area akin to a sanctuary. But here there is no altar - only a book with yet more names. Our communion is with dead - the ones who gave their lives so we might live.

Similar observations could be made of the National War Memorial in Canberra, Australia - often described simultaneously as Australia's 'most sacred, yet secular space'. (See Figure 2).

\footnotetext{
$\overline{12}$ David Martin, The Breaking of the Image, Oxford: Basil Blackwell, 1980, p. 61.

${ }^{13}$ See David Docherty, 'Reservoir Gods' in (eds.) M. Percy \& D. Walker, Restoring the Image: Essays on Religion and Society in Honour of David Martin, Sheffield: Sheffield Academic Press, 2001.
}

The central mausoleum is vast in height, and yet containing, intimate and womb-like in breadth. Light pours in through one central window open to the sky, and a dozen stained glass windows - the latter depicting not saints or religious figures, but rather representations of those who served in the armed services and lost lives in the two great wars: nurses, infantry, artillery, navy, air force and so forth. Indeed, the nurse who stands in the middle of one panel of windows can be likened to a Madonna, surrounded by Apostles. The mausoleum is a celebration and memorialisation of virtue, sacrifice and service of the few for the many; it is a testament of higher purposes; of brotherhood and sisterhood. Neither of these two illustrations are drawn from cathedrals. Yet both memorials are typical of what one would find in a cathedral - a kind of sacralisation of the highest virtues of civic life.

In March 2019, and as I sat in Guilford Cathedral, waiting for David's funeral, I was struck again by the testimony of the space that he had worshipped and ministered in for many decades: the vastness, purity and light. It was overpowering, yet encompassing; distancing, yet intimate; 'ours', yet 'other' The space spoke of God in our midst, and God beyond us. Then the funeral began, and all those gathered to worship, pray and mourn, knew that we were part of something that was both for us, yet wholly beyond us. Cathedrals are places of alterity, not homogeneity. They are here to provide an alternative from any standardised ecclesial fare. Cathedral Church witnesses the broader calling of the church, by providing a space that invites us to convene and to trespass; to dwell and delight in poetry and silence; to witness acts of hope and lament; to participate in worship that can provide both blessing and censure. Ultimately, cathedrals may stand as a proto-sign of a profoundly incorporative ecclesiology. As 
Fig. 2 A stained glass window in the Australian War Memorial, Canberra

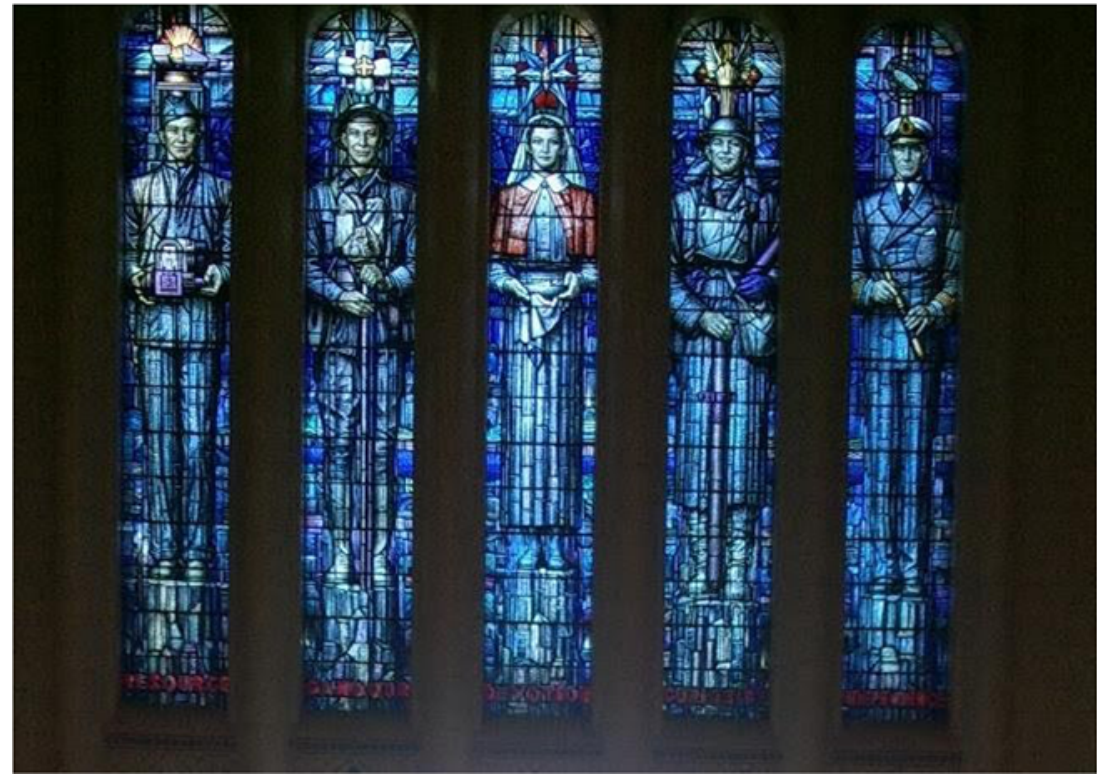

Albert Van Den Heuvel has argued, they are a symbol of diversity in unity; theatres of basic drama; Pentecostal laboratories; temples of dialogue; centres of creativity; clinics for public exorcism; places of international exchange; broadcasting stations for the voice of the poor; towers of reconciliation; motels for pilgrims and houses of vicarious feasts. A Cathedral is the hut of the Shepherd; and so the House of Christ. $^{14}$

I end on a festive note, and reflect that I am continually confounded by the thousands who attend Christ Church Cathedral at Christmas. But I suspect we should not be surprised at the continuing rise in the number of attendees and worshippers during this celebratory season. For there is a sense in which the spirit of Christmas - the cathedral that is offering the 'lowthreshold-high-reward' experience - expresses something of the true essence of English Anglicanism. That is to say, the services will embody a quality and commitment in pastoral and liturgical endeavour for all those attending, quite independent of any reciprocation on their part. ${ }^{15}$ In that sense, the ecclesiology expresses the theology: the Christ-child is for all, and not just the committed. At Christmastide, the Church of England, led by its Cathedrals, rediscovers and renews itself as a form of ecclesiology that expresses the particularity and theology of the incarnation, dwelling in the midst of the communities they serve. In gift, festivity and exuberance, new life and hope is celebrated in the darkest of seasons. Charity to all is affirmed, and the church once again resumes its vocation as the social skin of the nation, and a patterning of polity in civic society. The word made flesh dwells amongst us once again, full of grace and truth; and a symbol of enduring light amidst the darkness.

Open Access This article is licensed under a Creative Commons Attribution 4.0 International License, which permits use, sharing, adaptation, distribution and reproduction in any medium or format, as long as you give appropriate credit to the original author(s) and the source, provide a link to the Creative Commons licence, and indicate if changes were made. The images or other third party material in this article are included in the article's Creative Commons licence, unless indicated otherwise in a credit line to the material. If material is not included in the article's Creative Commons licence and your intended use is not permitted by statutory regulation or exceeds the permitted use, you will need to obtain permission directly from the copyright holder. To view a copy of this licence, visit http://creativecommons.org/licenses/by/4.0/.

Publisher's Note Springer Nature remains neutral with regard to jurisdictional claims in published maps and institutional affiliations.

The Very Revd. Professor Martyn Percy is Dean of Christ Church, Oxford, and a former Principal of Ripon College, Cuddesdon. He writes and teaches in the field of ecclesiology, and in the sociology of religion.

\footnotetext{
${ }^{14}$ Extract from Albert Van Den Heuvel's sermon dedicating Coventry Cathedral, 1962.

${ }^{15}$ For a discussion of the concept low-threshold-high-reward', see Martyn Percy, 'The Household of Faith', in Paul Avis \& Benjamin Guyer, (eds.), The Lambeth Conference: Theology, History, Polity and Purpose, London: Bloomsbury, 2017, pp. 316-340.
} 